\title{
The Effect of Good Government Governance on the Financial Reports Quality: The Case of Provincial Capital Governments in Indonesia
}

\author{
Nelly Masnila ${ }^{1}$, Riana Mayasari ${ }^{* *}$, Firmansyah Firmansyah $^{3}$, \\ Jovan Febriantoko ${ }^{4}$, Jamaliah Said ${ }^{5}$ \\ ${ }^{1,2,3,4}$ Departement of Accounting, State Polyechnic of Sriwijaya, Indonesia \\ ${ }^{5}$ Accounting Research Institute, Universiti Teknologi MARA, Malaysia \\ riana.mayasari@polsri.ac.id
}

\begin{abstract}
This study aimed to determine the relationship and effect of the GGG variable on the quality of the financial reports in municipal governments in Indonesia by implementing the IIAG (The Ibrahim Index of African Governance) indicator. The variables of this study consist of the participant, legal culture, transparency, responsiveness, public interest orientation, fairness, effectiveness and efficiency, accountability, strategic vision, and human development as independent variables and the quality of financial reports as dependent variables. The method in this study was quantitative, so it was found that partially, only responsive and accountability variables significantly affected the quality of the financial reports. Meanwhile, other independent variables such as participants, legal culture, transparency, public interest orientation, fairness, effectiveness and efficiency, strategic vision, and human development had no significant effect on the quality of financial reports. However, simultaneously, all independent variables had a significant effect on the quality of financial reports. The level of the coefficient of determination obtained was equal to Adj. R2 $=0.299$. It means that the quality of local government financial reports was influenced by the independent variable by $29.9 \%$, while $70.1 \%$ was influenced by other variables not examined in this study.
\end{abstract}

Keywords: Government Governance, Financial Report Quality, AG, Public Sector Accounting

\section{How to Cite:}

Masnila, N., Mayasari, R., Firmansyah, F., Febriantoko, J., and Said, J. (2021). The effect of good government governance on the financial reports quality : the case of provincial capital governments in Indonesia. International Journal of Business, Management and Economics, 2(4). 270 - 287. DOI: https://doi.org/10.47747/ijbme.v2i4.385

\section{Introduction}

Implementing a good and clean government needs to apply the concept of Good Government Governance (GGG). GGG is a concept of good governance. The National Committee for Governance Policy has the opinion that the government in Indonesia has a responsibility in implementing GGG standards applied by international standards. The process of implementing the power in the provision of public goods and services is called governance, 
while the best practice is called Good Government Governance (Rizal, 2015). In the implementation of Good Government Governance, it needs the participation from all parties, the government, and the community. Government actors have main role in the success of good governance. The economic crisis in a country can be a problem of good governance in Indonesia. Many problems have arisen in society due to the economic crisis which, if not addressed immediately, could disrupt the performance of the government as a whole. In Indonesia, It is still often the case, for example with soaring food prices due to mistakes in making export and import policies. As one of the tangible manifestations of the success or failure of the implemented government policies, namely the existence of a solid community and actively participating in the determination and implementation of a country policies.

Many studies related to GGG carried out with various different indicators. There is research that uses the GGG indicator developed by the United Nations Development Program (UNDP). The concept that UNDP has developed regarding good governance is more emphasized on the political, economic, and administrative aspects of state management.

(Mardiasmo, 2002) reveals that the characteristics or principles developed in the implementation of good governance include community participation, upholding the rule of law, transparency, responsiveness, consensus orientation, equality, effectiveness and efficiency, accountability and strategic vision. Another performance assessment that can be implemented in Indonesia is The Ibrahim Index of African Governance/IIAG (Farrington, 2010). This tool is used to measure and monitor governance performance in countries on the African continent. The main pillars in the assessment of governance in the index are (1) security and rule of law, (2) participation, right and inclusion, (3) foundation for economic opportunity, and (4) human development (Awojobi, 2014). The IIAG assessment indicators are generally used to assess developing countries. Therefore, IIAG can be implemented in Indonesia because it appropriates with the current conditions in Indonesia.

Research conducted by Maryani with the title "The Effect of Good Governance and Internal Control on the Local Government Financial Reports Quality Case Study at the Regional Revenue and Financial Management Office (DPPKAD) of Bintan Regency also states that GGG had a simultaneous effect on the quality of financial reports (Maryani, 2016). Another study conducted by Masnun (2018)with the title "Good Governance and the Quality of Government Financial Reports: A Study in the Regional Government of Jambi Province," also shows the same results, namely that GGG has a simultaneous effect on the quality of financial reports (Masnun, 2018). This research was also conducted by T. Herawati and D. Nopianti with the title "The Influence of the Implementation of Government Accounting Standards and Good Governance on the Local Government Financial Reports Quality" also showed significant results and had an effect on financial reports (Herawati \& Nopianti, 2017). The novelty of this research is to conduct a more in-depth and comprehensive analysis of the determinants of GGG on the quality of financial reports through a combination of the GGG index from UNDP and IIAG. This study uses 10 GGG indicators which are a reconciliation of indicators developed by UNDP and IIAG in assessing government performance. In general, the assessment of local government GGG implementation is only assessed using the GGG index developed by UNDP or other GGG indices. The index is less than 10 indicators and does not include the Human Development Index which affects the quality of financial reports in the Provincial Capital Regional Governments in Indonesia.

Based on the description, this study was conducted to determine the determinants of GGG 
Vol. 2, No. 4, November 2021

using a combination of the GGG index from UNDP and IIAG on the Financial Reports Quality produced by local governments.

From the above background, the formulation of the research problem wass how the influence of GGG on the quality of the financial reports of the Provincial Capital Government in Indonesia in 2016-2018.

The purpose of this study was determine the relationship and influence between the GGG variable on the quality of financial reports in city governments in Indonesia, especially in the provincial capital in 2016-2018.

\section{Literature Review}

The indicators used for the GGG assessment are based on research (Rossieta et al., 2017) namely (1) democracy, (2) transparency, (3) accountability, (4) culture of law, and (5) fairness and equality. The Ibrahim Index of African Governance (IIAG) uses 4 indicators in assessing GGG. These indicators are (1) security and rule of law, (2) participation, right and inclusion, (3) foundation for economic opportunity, and (4) human development ("2017 Ibrahim Index of African Governance," 2017). UNDP in (Duarmas et al., 2016) uses 9 indicators of GGG, namely, (1) Participants, (2) legal certainty, (3) transparency, (4) responsibility, (5) agreementoriented, (6) fairness, (7) effectiveness and efficiency, (8) accountability, (9) strategic vision. Research by (Jatmiko \& Lestiawan, 2016) measures GGG with 5 indicators, namely (1) transparency principles, (2) accountability principles, (3) public participation principles, (4) justice principles, and (5) responsibility principles. Research (Handayani, 2012) concludes that the opinion given by the auditor reflects the extent of the good governance principles implemented by the government. Examination of LKPP, LKKL and LKPD is intended to provide reasonable assurance that the financial reports have complied with government accounting standards, laws and regulations and internal control.

Many studies related to GGG have been carried out with different indicators. Likewise, research related to the quality of financial reports. Efforts made to develop research by reconciling existing research criteria. This research was conducted with the aim of reconciling the criteria or indicators of GGG as determined by the United Nations Development Program (UNDP) and The Ibrahim Index of African Governance (IIAG) that relates it to The Auditory Board of The Republic Indonesia opinion on LKPD and follow-up on the Auditory Board of The Republic Indonesia finding.

The independent variables are human resource compensation, government accounting standards, good governance have a positive impact on the financial reporting quality variables (Agatha, 2020). Good governance has an influence on the quality of financial reporting in Manado City Government, which means that the better the implementation of good governance, the better the quality of financial reporting of local governments (Maramis et al., 2018). Good governance, application of government accounting standards, system of internal control, and efficiency of government officials simultaneously have a significant impact on the quality of financial reporting. (Kesuma et al., 2017). Examination of the regional government financial reports must see the quality of accountability (Masnila, 2014). GGG implementation can be supported through the preparation of results-oriented work plans (Mayasari et al., 2021). In addition, it must also prepare results-oriented accountability reports as well (Mayasari, 2016). The practice and implementation of good governance by public organizations has a significant effect on system integrity (Said et al., 2016). Management 
Vol. 2, No. 4, November 2021

Accounting Information System (SIAM), decentralization, and good budget target clarity can affect indicators in GGG, namely budget preparation performance (Febrianty \& Febriantoko, 2017). The government financial capacity will improve government administration in accordance with GGG(Sunardi et al., 2020). The preparation of government accountability reports needs the improvment that can be evaluated through a qualitative approach Febriantoko \& Febrianty, 2017).

The following is a figure of the research framework:

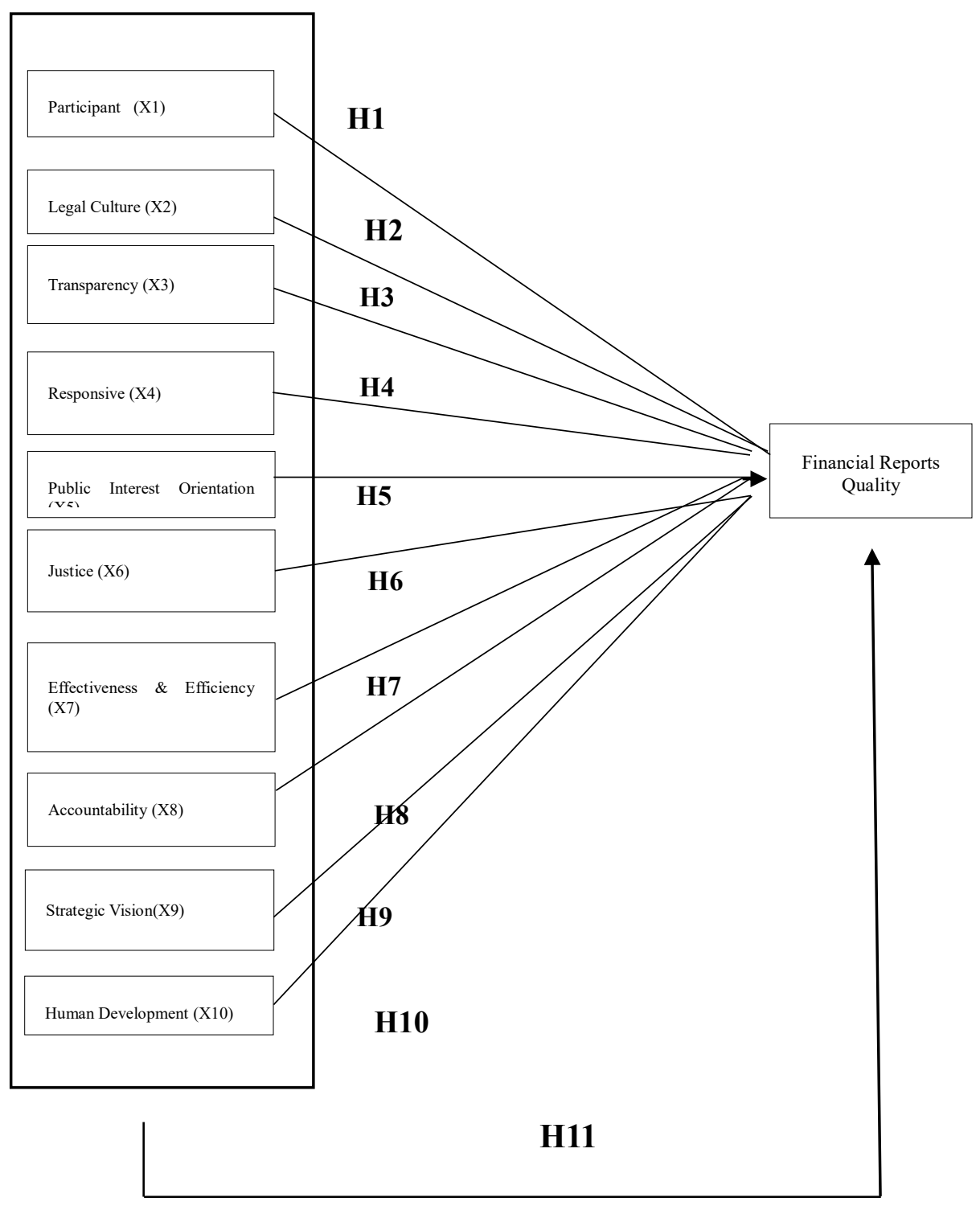

Figure 1. Research Framework

\section{Research Method}

The research was concducted at the Audit Board of the Republic of Indonesia. The research as conducted for 8 months after the announcement of acceptance. The object of research was the 
provincial capital government in Indonesia. Based on this, the population in this study was all the provincial capital region governments in Indonesia, amounting to 34 provincial capitals. The sampling technique used was purposive sampling. The sample used in this study was a total of 28 provincial capitals for the 2016-2018 periods. The data collection techniques used in this research were literature study and documentation. The data used in this study were secondary data in quantitative form. The data obtained by researchers indirectly through intermediary media (Sekaran \& Bougie, 2013). Generally, this data were obtained through intermediary media sourced from reports, books, records, or archives, both published and unpublished (Sugiyono, 2017). The data were able to provide a clear picture of the influence of GGG on Financial Report Quality. Test the validity of the data in this study using validity and reliability tests. The data analysis technique used in this study is causality analysis using multiple linear regression analysis. This analysis looks for the determinant of the independent variable with the dependent variable. This analysis differs from simple linear regression in that the number of independent variables which are explanatory variables is more than one.

The reference equation used in this study is

$Y=a 0+b 1 \times 1+b 2 \times 2+b 3 \times 3+b 4 \times 4+b 5 \times 5+b 6 \times 6+b 7 \times 7+b 8 \times 8+b 9 \times 9+b 10 \times 10+e$.

This study uses variables. The indicator variables for participation (X1) are the existence of regional regulations on public service standards, the existence of regional regulations on public consultation, and the number of regional people's representative assembly decisions followed by local governments. Indicators of legal culture variables (X2) are, number of local government regulations produced, number of government regulations repealed, number of draft regional government regulation approved by regional people's representative assembly, number of regent / mayor decisions followed, and number of regent / mayor regulations followed. The transparency variable (X3) indicator is the availability of government social media that is accessible to the public, the availability of personnel information systems, and the availability of e-procurement. Indicator of responsiveness variable (X4) is the timeliness of the determination of the district budget, the ratio of civil servants to the population, and the suitability of local government organizations based on Government Regulation Number 41 of 2007. Indicators of community interest orientation variables (X5) are the appropriateness of development priorities, the number of mandatory matters performed by the local government, the number of mandatory matters applied to the Minimum Service Standards, the existence of regional regulations on building permit, the existence of regional regulations on sex workers and sellers streets, the existence of regulations on cleanliness, the existence of regional regulations on RT / RW, the ratio of budget surplus to the total income, the ratio of house building permit, the ratio of civil service police members to the population. The fairness variable (X6) has indicators of general expenditure allocation to general allocation fund, general expenditure allocation to total local budget, and expenditure allocation for education and health. The evaluation indicators for the efficiency and effectiveness variables (X7) are balanced fund absorbed against plan, increased locally-generated revenue, realization of expenditure against budget, Total locally-generated revenue for all income in Local Budget, realization of locally-generated revenue to potential locally-generated revenue, E-identity card processing cost, total percentage of community E- identity card management. Accountability variable (X8) uses indicators of assessment of Audit Board of the Republic of Indonesia audit 
Vol. 2, No. 4, November 2021

opinion on local government financial statements, findings of Audit Board of the Republic of Indonesia followed, existence of regional regulations on regional financial management, Percentage of expenditure for basic services, timeliness of delivery of Local Government Performance Reports, timeliness of delivery of administrative reports government, timeliness of local government financial reporting. Changing strategic decision (X9) cooperative relations with other regions, Number of investment approvals, awards received from central government to local governments. the human development variable (x10) uses the local government organizations education budget indicator for total local budget, local government organization health estimate to total local budget expenditure, local government organizations manpower estimate to total local budget expenditure, number of national education programs implemented by local government organizations, number of national health programs implemented by local government organizations, number of education development planning documents available, number of health sector development planning documents available, number of workforce development planning documents available. the assessment indicator for financial reporting quality (y) is the suitability of using accounts with government accounting standards, financial statements accompanied by financial ratios, so that they can be used to predict the future, timeliness of financial reporting, completeness of financial statements, non -ownership of assets supported by valid evidence, audit board of the republic of indonesia audit opinion on local government financial report for the last 3 years, incomplete / invalid evidence of liability, number of other equity correction items in the equity change statement, value of other equity corrections in the equity change statement, graphics and tables can explain the information presented, and the statement well-organized finances.. this research model measured the determinant between 10 (ten) variable $\mathrm{x}$ incorporated in GGG and 1 (one) variable y. the main activity of this model was hypothesis testing to determine whether the hypothesis was accepted or rejected.

\section{Findings and Discussions}

\section{Finding}

\section{Data Quality Test}

Table 1 Results of Realibility Test

\section{Reliability Statistics}

\begin{tabular}{cr} 
Cronbach's Alpha & N of Items \\
\hline ,518 & 10 \\
\hline Source: Processed Data , 2021
\end{tabular}

Reliability test with Cronbach's Alpha formula, obtained results greater than 0.05 that was reliable.

Table 2 Validity Test Results

\begin{tabular}{cc}
\hline Variable & $\begin{array}{c}\text { Pearson } \\
\text { Correlation }\end{array}$ \\
\hline Participant (X1) &, $743^{* *}$ \\
\hline
\end{tabular}


Vol. 2, No. 4, November 2021

\begin{tabular}{cc}
\hline Legal Culture (X2) &, $373^{* *}$ \\
Transparency (X3) &, $230^{*}$ \\
Responsive (X4) &, $246^{*}$ \\
Public Interest Orientation (PIO) (X5) &, $141^{*}$ \\
Justice (X6) &, $277^{*}$ \\
Effectiveness \& Efficiency (X7) &, $488^{* *}$ \\
Accountability (X8) &, $562^{* *}$ \\
Strategic Vision(X9) &, $695^{* *}$ \\
Human Development(X10) &, $398^{* *}$ \\
\hline
\end{tabular}

Source: Processed Data, 2021

The results of the validity test above showed a positive value and the Pearson Correlation was above 0.05 . It means all independent variables were valid.

\section{Clasic Assumption Test}

\section{Normality Test Results}

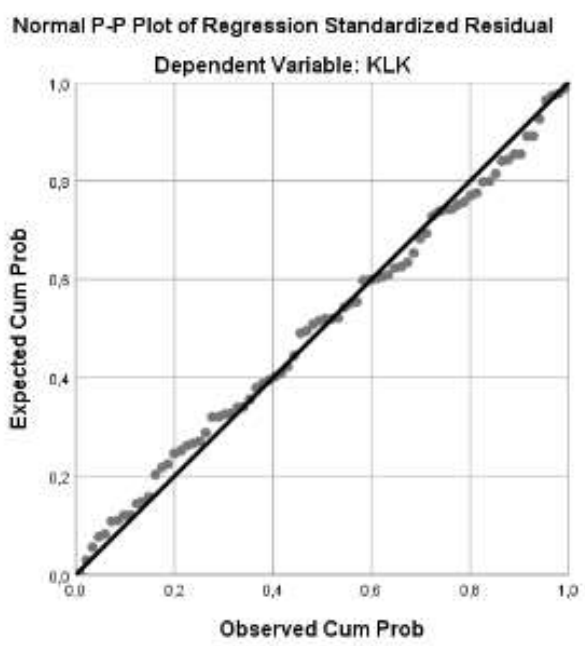

Source: Processed Data, 2021

Figure 2 Normal Probability Plot

In the figure of normal probability plot results, it can be seen that the results distributed around the diagonal line and follow the direction of the diagonal line. Based on the data can be detected normally and the regression model met the requirements as the normality assumption. Thus, data on transparency, accountability, and regional financial management were normally distributed. KLK is the quality of financial reporting 


\section{Multicollinearity Test Results}

Table 3 Multicollinearity Test Results

\begin{tabular}{lcr}
\hline \multicolumn{3}{c}{ Coefficients $^{\mathrm{a}}$} \\
Model & \multicolumn{2}{c}{ Collinearity Statistics } \\
\cline { 2 - 3 } Tolerance & VIF \\
\hline (Constant) & 0,652 & 1,533 \\
Participant & 0,831 & 1,203 \\
Legal Culture & 0,861 & 1,162 \\
Transparency & 0,942 & 1,062 \\
Responsive & 0,86 & 1,162 \\
Public Interest Orientation & 0,875 & 1,143 \\
Justice & 0,788 & 1,269 \\
Effectiveness \& Efficiency & 0,719 & 1,391 \\
Accountability & 0,689 & 1,452 \\
Strategic Vision & 0,833 & 1,2 \\
Human Development & & \\
\hline
\end{tabular}

A. Dependent Variable: KLK

Source: Processed Data, 2021

The table above showed the VIF value $<10.00$ for all independent variables, as well as the Tolerance value $>0.100$ so there was no multicollinearity in the data of this study.

\section{Heteroscedasticity Test Results}

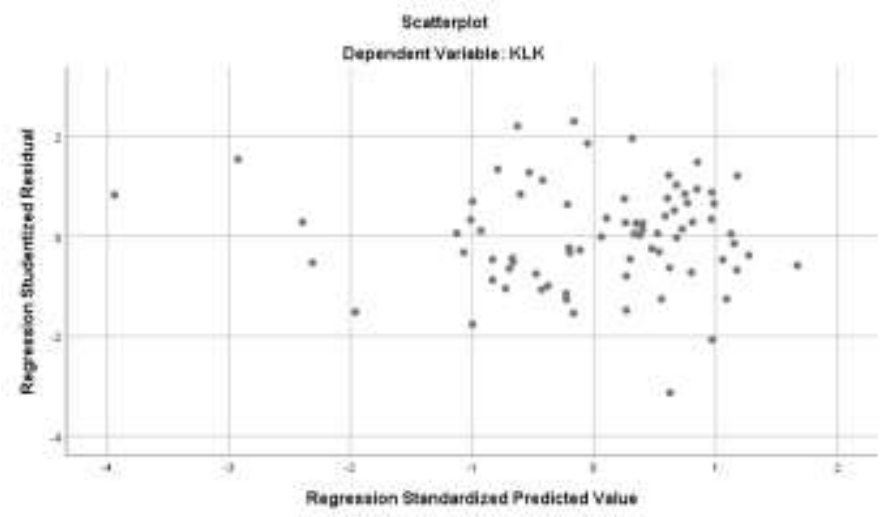

Figure 3. Hasil Uji Heteroskedastisitas

Source: Processed Data, 2021 
From the figure above, there was no visible pattern in the data distribution. Thus, there was no heteroscedasticity in this data.

\section{Autocorrelation Test Results}

Table 4 Autocorrelation Test Results

\begin{tabular}{|c|c|c|c|c|c|}
\hline \multicolumn{6}{|c|}{ Model Summary } \\
\hline Model & $\mathrm{R}$ & R Square & $\begin{array}{l}\text { Adjusted R } \\
\text { Square }\end{array}$ & $\begin{array}{l}\text { Std. Error of the } \\
\text { Estimate }\end{array}$ & $\begin{array}{l}\text { Durbin- } \\
\text { Watson }\end{array}$ \\
\hline &, $546^{\mathrm{a}}$ & 0,299 & 0,194 & 6,03021 & 1,460 \\
\hline
\end{tabular}

a. Predictors: (Constant), Human Development, Justice, Responsive, Legal Culture, Transparency, Public Interest Orientation, Accountability, Effectiveness \& Efficiency, Strategic Vision, Participant

b. Dependent Variable: KLK

Source: Processed Data, 2021

Based on the results above, it is known that the Durbin Watson value of 1.460 laid between 1.357 to 2.643. It can be concluded that there was no autocorrelation in this regression model.

\section{Hypothesis Test}

\section{F-test Results}

Table 5 Simultaneous Test Results (F)

\begin{tabular}{|c|c|c|c|c|c|}
\hline \multicolumn{6}{|c|}{ ANOVA $^{a}$} \\
\hline Model & Sum of Squares & $\mathrm{df}$ & Mean Square & $\mathrm{F}$ & Sig. \\
\hline 1 Regression & 1037,229 & 10 & 103,723 & 2,852 &, $005^{b}$ \\
\hline Residual & 2436,347 & 67 & 36,363 & & \\
\hline Total & 3473,575 & 77 & & & \\
\hline
\end{tabular}

a. Dependent Variable: KLK

b. Predictors: (Constant), Human Development, Justice, Responsive, Legal Culture, Transparency, Public Interest Orientation, Accountability, Effectiveness \& Efficiency, Strategic Vision, Participant

Source: Processed Data, 2021

It can be concluded that all independent variables (X) simultaneously affected the dependent variable $(Y)$.

\section{Partial t Test Results}

Table 6 Partial t Test Results

\begin{tabular}{|c|c|c|c|c|c|c|c|}
\hline \multicolumn{8}{|c|}{ Coefficients $^{\mathrm{a}}$} \\
\hline \multirow[b]{2}{*}{ Model } & \multicolumn{2}{|c|}{$\begin{array}{l}\text { Unstandardized } \\
\text { Coefficients }\end{array}$} & $\begin{array}{c}\text { Standardized } \\
\text { Coefficients }\end{array}$ & \multirow[b]{2}{*}{$\mathrm{t}$} & \multirow[b]{2}{*}{ Sig. } & \multicolumn{2}{|c|}{$\begin{array}{l}\text { Collinearity } \\
\text { Statistics }\end{array}$} \\
\hline & B & $\begin{array}{l}\text { Std. } \\
\text { Error }\end{array}$ & Beta & & & Tolerance & VIF \\
\hline 1 (Constant) & $-10,544$ & 30,208 & & $-0,349$ & 0,728 & & \\
\hline Participant & 0,156 & 0,450 & 0,044 & 0,346 & 0,730 & 0,652 & 1,533 \\
\hline
\end{tabular}


Vol. 2, No. 4, November 2021

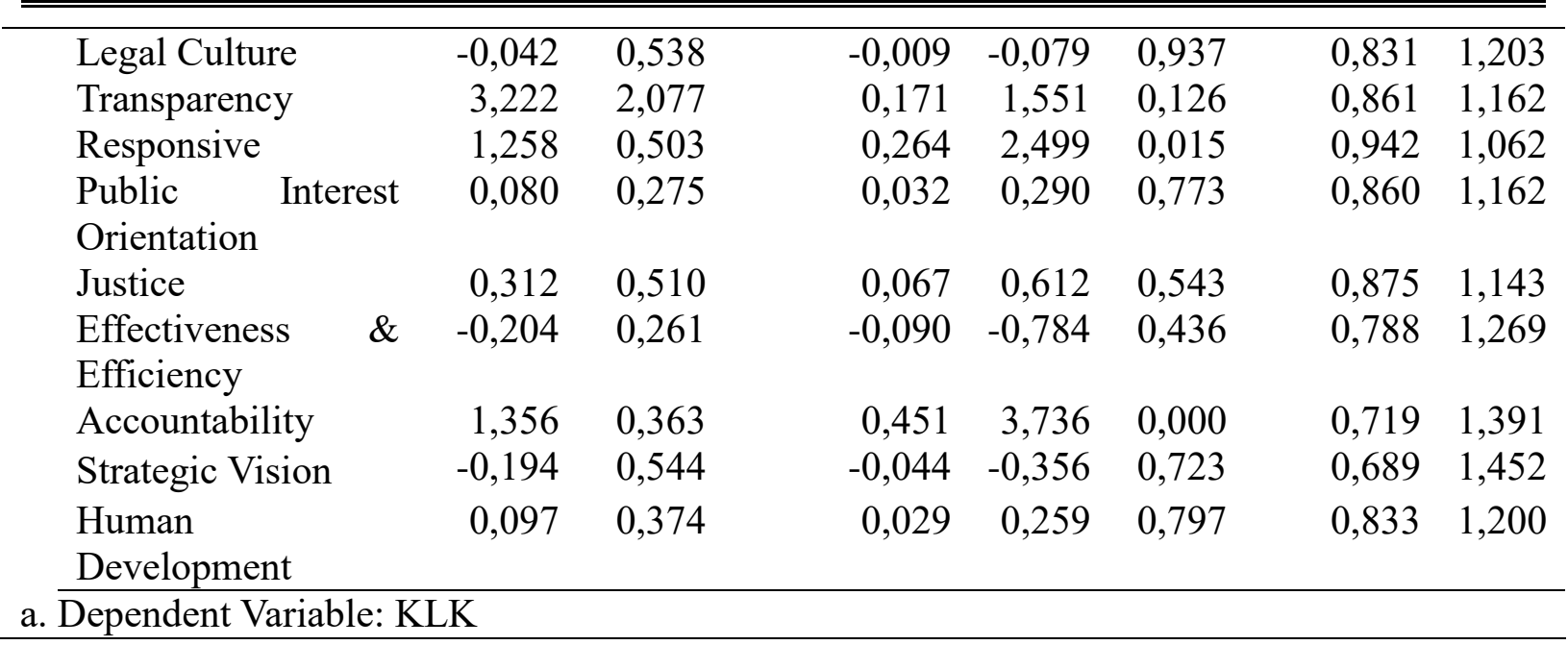

Source: Processed Data, 2021

From the data above, it showed that only Responsiveness (X4) and Accountability (X8) had a partial effect on the Quality of Financial reports (Y), because the value of sig was $<0.05$. Other variables had no effect on the Quality of Financial reports.

From table above found the multiple lineqar regression as below:

$$
\begin{aligned}
\mathrm{Y}= & -10,544+0,156 \mathrm{X} 1-0,042 \mathrm{X} 2+3,222 \mathrm{X} 3+1,258 \mathrm{X} 4+0,080 \mathrm{X} 5+0,312 \mathrm{X} 6-0,204 \\
& \mathrm{X} 7+1,356 \mathrm{X} 8-0,194 \mathrm{X} 9+0,097 \mathrm{X} 10
\end{aligned}
$$

The description of the equation is:

1. The regression equation above shows a constant value of $-10,544$. This means that if the variable of good governance is considered constant, the quality of financial reports will be constant at $-10,544$.

2. The b1 value is 0.156 , it means the participant variable has a positive influence on the quality of financial reports.

3. The value of $\mathrm{b} 2$ is -0.042 , it means the legal culture variable has a negative influence on the quality of financial reports.

4. The value of $b 3$ is 3.222 , it means the transparency variable has a positive effect on the quality of financial reports.

5. The value of b4 is 1.258 , it means the responsive variable has a positive effect on the quality of financial reports.

6. The value of b5 is 0.080 , it means the variable orientation of public interest has a positive effect on the quality of financial reports.

7. The value of $b 6$ is 0.312 , it means the variable of justice has a positive effect on the quality of financial reports.

8. The value of $b 7$ is -0.204 , it means the effectiveness and efficiency variables have a negative effect on the quality of financial reports. 
9. The $b 8$ value is 1.356 , which means the accountability variable has a positive effect on the quality of financial reports,

10. The value of $\mathrm{b} 9$ is -0.194 , it means the strategic vision variable has a negative effect on the quality of financial reports.

11. The value of b10 is 0.097 , it means the human development variable has a positive effect on the quality of financial reports.

\section{Coefficient of Determination Results $\left(\mathbf{R}^{2}\right)$}

Table 7 Coefficient of Determination Test Results

\begin{tabular}{rrrrrr}
\hline \multicolumn{6}{c}{ Model Summary $^{\mathbf{b}}$} \\
\hline \multirow{2}{*}{ Model } & \multirow{2}{*}{$\mathrm{R}$} & \multirow{2}{*}{ R Square } & $\begin{array}{c}\text { Adjusted R } \\
\text { Square }\end{array}$ & $\begin{array}{c}\text { Std. Error of the } \\
\text { Estimate }\end{array}$ & $\begin{array}{c}\text { Durbin- } \\
\text { Watson }\end{array}$ \\
\hline 1 &, $546^{\text {a }}$ & 0,299 & 0,194 & 6,03021 & 1,46 \\
\hline
\end{tabular}

a. Predictors: (Constant), Human Development, Justice, Responsive, Legal

Culture, Transparency, Public Interest Orientation, Accountability, Effectiveness

\& Efficiency, Strategic Vision, Participant

b. Dependent Variable: KLK

Source: Processed Data, 2021

The level of the coefficient of determination obtained was equal to Adj. R2 $=0.299$. It means that the quality of local government financial reports was influenced by the independent variable by $29.9 \%$, while $70.1 \%$ was influenced by other variables not examined in this study.

\section{Discussion}

Based on the results and data scoring, it can be seen that Bengkulu province had the lowest GGG effect, that was only $79.49 \%$ and the highest GGG effect was in NTB province with Mataram as the capital that was $93.93 \%$. For the western part of Indonesia, it is known that the GGG index was $88.96 \%$, Central Indonesia was $90.76 \%$, and Eastern Indonesia was $86.53 \%$. Thus, from the three regions, it can be seen that the regional governments in the central part of Indonesia had the highest GGG compared to the regional governments in the western and eastern parts of Indonesia. It shows that local governments in the central part of Indonesia have been able to apply the GGG concept so that they can produce quality regional financial reports.

The results of the partial test also state that the sig value of the variable participant was $0.730>0.05$. This means that participants have no significant effect on the quality of financial reports. Research conducted by (Iswahyudi et al., 2016) also showed that participants had no effect on regional financial supervision.

Legal Culture had no significant effect on the financial report quality. It can be seen from the sig value of $0.937>0.05$. The results of another study stated that culture had no significant effect as the carried out by Meidylisa Patty in 2019. That the research conducted showed that 
Vol. 2, No. 4, November 2021

the application of good governance and culture together had not been able to improve the quality of reports (Patty, 2019).

Similarly, transparency had no significant effect on the financial report quality, because the sig value was $0.126>0.05$. Research conducted in 2017 by (Sari, 2017) and (Azizah et al., 2015) showed the same results. Likewise with the results obtained, transparency was not significant to the quality of financial reports.

In contrast to the responsive variable with significant effect on the Quality of Financial reports. This can be seen from the value of sig $0.015<0.05$. The results of this research were in line with research (Khairaningrum \& Rahma, 2020) that states that responsiveness had a significant effect on the quality of financial reports.

The partial test on the community interest orientation variable obtained a sig value of $0.773>$ 0.05. It shows that the Public Interest Orientation had no significant effect on the financial report quality. According to (Forsyth, 1980) said that ethical orientation is controlled by two characteristics, namely idealism and relativism. Idealism is an ethical orientation refers to the extent to which a person is concerned with the welfare of others and strives not to harm others. Relativism is an ethical orientation that refers to the rejection of universal or absolute moral principles (rules). At this time, the majority are not oriented to the public interest, only interests that are personally beneficial. This is the biggest problem today and a problem that many people complain about (Tupan, 2016). This study is in line with research conducted by (Ulum, 2005) which shows that the orientation variable has no effect on independence.

Justice variable was declared as insignificant with a value of $0.543>0.05$. Justice in Indonesia still stands of certain groups. Research conducted by (Asiam, 2020) stated that ethics in preparing reports should not only aim to provide benefits to internal parties, but also to provide benefits to external parties. It aims to improve the quality of financial reports so that the information presented does not harm any party.

effectiveness and efficiency had no significant effect on the financial reports quality. it can be seen from the sig value of $0.436>0.05$. the result is not in line with research conducted by (Herawati \& Nopianti, 2017) that had significant effect on the financial reports quality. Effectiveness describes the level of ability of the regional government in realizing the planned Regional Original Income (PAD) then compared with the target based on the real potential of the region. The higher the effectiveness ratio, the better the local government ability to manage financial reports. Regional Financial Efficiency is a ratio that describes and shows the level of comparison between the amount of costs that have been incurred for the realization of regional expenditures with the realization of revenues that have been received. For this reason, the regional government needs to calculate carefully and precisely with the level of costs has spent to realize the entire level of income it has received so that it can be seen whether the implementation of the income collection activities is efficient or not (Siregar $\& \mathrm{~S}$, 2020).

Accountability had a significant effect on the financial reports quality with a sig value of $0.000<0.05$. The same result obtained by M. Anas in 2020 . There was a significant effect of accountability on the quality of financial report information indicating that village officials are able to carry out their duties and functions in government responsibly. Accountability also occured due to supervision and audit by related parties, for example: sub-district head, inspectorate, Development Finance Comptroller (DFC) and The Audit Board of the Republic 
of Indonesia (Anas et al., 2021). It should be implemented by local governments in order to produce accountable and quality financial reports for the public.

The Strategic vision variable had no significant effect on the quality of financial reports with sig value of $0.723>0.05$. Government activities in various fields and levels should be based on a clear vision and mission and the timeframe for its achievement and equipped with implementation strategies that are targeted, beneficial and sustainable (Amalia, 2018). This research which stated that the strategy determined by the policy makers was to increase the capacity of human resources in accordance with the criteria and level of education that became the basis for producing quality financial reports. The role and responsibility of the leadership in preparing reports is also very necessary to produce fair and transparent financial reports.

The human development variable obtained a sig value of $0.797>0.05$. It shows that Human Development had no significant effect on the financial reports quality. A similar study was also conducted by (Harliyani \& Haryadi, 2016) which stated that the ratio of regional financial dependence, PAD effectiveness and PAD efficiency did not have a significant influence on human development. According to the Ibrahim Index of African Governance (IIAG) developed by the Ibrahim Foundation, this indicator is measured by comparing Local government working unit (LGWU) budgets for Education, Health and employment to total APBD expenditures. The Human Development Index (HDI), specifically measures the achievement of human development using several basic components of quality of life. This index is calculated based on data that can describe the four components, namely the achievement of a long and healthy life that represents the health sector; literacy rate, school participation and average length of schooling which measures the performance of development in the education sector; and the ability of people's purchasing power to a number of basic needs as seen from the average amount of per capita expenditure as an income approach (Rustariyuni, 2014). But in reality, the government has not been able to fully reach human development based on the components.

Based on F-test results, the independent variable on GGG had a simultaneous effect on the quality of financial reports. It can be seen from the value of sig $0.005<0.05$. Similar results were also obtained from research conducted by Maryani, Herawati and Nopianti in 2017 and Masnun in 2018 stated that GGG affected the quality of financial reports simultaneously. However, to improve the local government financial reports quality needs more attention to the Implementation of Government Accounting Standards and good governance by increasing human resources with high competence and integrity who understand the standards and rules.

\section{Conclusion}

It can be concluded partially only responsive and accountability variables significantly affect the quality of financial reports. other independent variables such as participation, legal culture, transparancy of public interest orientation, fairness, effectiveness and efficiency, strategic vision, and human development had no significant effect on the quality of financial reports. Simultaneously, all independent variables had a significant effect on the Quality of Financial reports. This study only collected data from 2016-2018 and only consisted of a few samples of provincial capitals in Indonesia. It is expected that in the future competent parties in the field of financial management from government or non-government may provide input and updates in managing finances so that every local government in Indonesia can produce quality financial reports. For further research, it is expected to expand the sample of the 
Vol. 2, No. 4, November 2021

research conducted by adding other indicators considered to have an influence and using data with the latest year.

\section{References}

2017 Ibrahim Index of African Governance. (2017). In Africa Research Bulletin: Political, Social and Cultural Series (Vol. 54, Issue 11, p. 21647). Wiley. https://doi.org/10.1111/j.1467-825x.2017.07977.x

Agatha, K. V. (2020). Pengaruh kompetensi sumber daya manusia,penerapan standar akuntansi pemerintah dan good governance terhadap kualitas laporan keuangan. E-Jra, $09(02), 47-57$.

Amalia, S. (2018). Reformasi Birokrasi 4.0: Strategi Menghadapi Revolusi Industri 4.0. Jurnal Wacana Kinerja: Kajian Praktis-Akademis Kinerja Dan Administrasi Pelayanan Publik, 21(2), 1-18. https://doi.org/10.31845/jwk.v21i2.133

Anas, M., Forijati, R., \& Muchson, M. (2021). Pengaruh Good Public Governance (Gpg) Terhadap Kualitas Informasi Laporan Keuangan Pemerintahan Desa Di Kabupaten Kediri. Jurnal Akuntansi Dan Ekonomi, 6(1), 2-12. https://doi.org/10.29407/jae.v6i1.15722

Asiam, S. (2020). Etika Penyusunan Laporan Keuangan Dalam Meningkatkan Kualitas Laporan Keuangan; Ditinjau Dari Perspektif Islam. Jurnal Tabarru': Islamic Banking and Finance, 3(2), 128-136. https://doi.org/https://doi.org/10.25299/jtb.2020.vol3(2).5719

Awojobi, O. N. (2014). Using Ibrahim Index of African Governance in Evaluating Nigerian Democratic Governance. International Journal of Contemporary Applied Sciences, 1(1), 75-92.

https://www.researchgate.net/profile/OladayoAwojobi/publication/271852865_Using_Ibrahim_Index_of_African_Governance_in_Ev aluating_Nigerian_Democratic_Governance/links/54d52c200cf2970e $4 \mathrm{e} 645 \mathrm{bcb} / \overline{\mathrm{Usin}}$ Ibrahim-Index-of-African-Governance-in-Evaluating-Nigerian-DemocraticGovernance.pdf

Azizah, N., -, J., \& Setiawan, A. R. (2015). Penyajian Laporan Keuangan, Aksesibilitas Laporan Keuangan, dan Sistem Pengendalian Internal Pemerintah sebagai Determinan Transparansi dan Akuntabilitas Pengelolaan Keuangan Daerah. Journal of Research and Applications: Accounting and Management, 1(2), 111. https://doi.org/10.18382/jraam.v1i2.18

Duarmas, D., Rumapea, P., \& Rompas, W. Y. (2016). Prinsip-Prinsip Good Governance Dalam Pelayanan Publik Di Kantor Camat Kormomolin Kabupaten Maluku Tenggara Barat. Jurnal Administrasi Publik, 1(37).

Farrington, C. (2010). Putting good governance into practice II: Critiquing and extending the Ibrahim Index of African governance. Progress in Development Studies, 10(1), 81-86. https://doi.org/10.1177/146499340901000106

Febriantoko, J., \& Febrianty. (2017). Proses Penyusunan Dokumen Perencanaan Dan Laporan Pertanggung Jawaban Pemerintah Daerah Di Indonesia: Pendekatan Kualitatif. Media Trend, 12((2)), 143-155. 
Vol. 2, No. 4, November 2021

https://doi.org/http://dx.doi.org/10.21107/mediatrend.v12i2.3067

Febrianty, F., \& Febriantoko, J. (2017). Pengaruh Implementasi Sistem Informasi Akuntansi Manajemen (SIAM), Desentralisasi, dan Kejelasan Sasaran Anggaran Terhadap Kinerja Penyusunan Anggaran, mpra.ub.uni-muenchen.de. https://mpra.ub.unimuenchen.de/90937/2/896

Forsyth, D. R. (1980). A taxonomy of ethical ideologies. In Journal of Personality and Social Psychology (Vol. 39, Issue 1, pp. 175-184). https://doi.org/10.1037//0022-3514.39.1.175

Handayani, D. (2012). Good Governance dan Kualitas Laporan Keuangan Pemerintah. Jurnal Akuntansi Keuangan Dan Bisnis, 5(2), 12-16.

Harliyani, E. M., \& Haryadi, H. (2016). Pengaruh Kinerja Keuangan Pemerintah Daerah Terhadap Indeks Pembangunan Manusia di Provinsi Jambi. Jurnal Perspektif Pembiayaan Dan Pembangunan Daerah, 3(3 SE-), 129-140. https://onlinejournal.unja.ac.id/JES/article/view/3514

Herawati, T., \& Nopianti, D. (2017). Pengaruh Penerapan Standar Akuntansi Pemerintahan dan Good Governance Terhadap Kualitas Laporan Keuangan Pemerintah Daerah. STAR Study \& Accounting Research, XIV(2), 10-45.

Iswahyudi, A., Triyuwono, I., \& Achsin, M. (2016). Hubungan Pemahaman Akuntabilitas, Transparansi, Partisipasi, Value For Money Dan Good Governance (Studi Empiris pada SKPD di Kabupaten Lumajang). Jurnal Ilmiah Akuntansi, 1(2), 151-166. https://doi.org/http://dx.doi.org/10.23887/jia.v1i2.9992

Jatmiko, B., \& Lestiawan, H. Y. (2016). Good Governance Government And The Effect On Local Government Performance ( Survey On Gunung Kidul District Government Of Indonesia ). Repository Universitas Muhammadiyah Yogyakarta, 14(14), 981-997.

Kesuma, D. P., Anwar, C., \& Darmansyah. (2017). Pengaruh Good Governance, Penerapan Standar Akuntansi Pemerintah, Sistem Pengendalian Internal Pemerintah dan Kompetensi Aparatur Pemerintah Terhadap Kualitas Laporan Keuangan Pemerintah Pada Satuan Kerja Kementerian Pariwisata. Jurnal Ilmiah Widya Ekonomika, 1(2), 141-146.

Khairaningrum, M., \& Rahma, N. A. (2020). Pengaruh Penerapan Good Corporate Governance (Gcg) Terhadap Kualitas Laporan Keuangan Pada Pt Iron Bird. Logistic and Accounting Development Journal, 1(1), 42-53.

Maramis, M. M., Morasa, J., \& Wokas, H. R. N. (2018). Pengaruh Penerapan Good Governance Dan Sistem Akuntansi Keuangan Terhadap Kualitas Laporan Keuangan Pada Pemerintah Kota Manado. Going Concern : Jurnal Riset Akuntansi, 13(04), 563570. https://doi.org/10.32400/gc.13.03.20685.2018

Mardiasmo. (2002). Elaborasi Reformasi Akuntansi Sektor Publik: Telaah Kritis Terhadap Upaya Aktualisasi Kebutuhan Sistem Akuntansi Keuangan Pemerintah Daerah. Journal Akuntansi \& Auditing Indonesia, 6(1), 63-82.

Maryani, N. I. (2016). Pengaruh Good Governance Dan Pengendalian Internal Terhadap Kualitas Laporan Keuangan Pemerintah Daerah (Studi Kasus Pada Dinas Pendapatan dan Pengelolaan Keuangan Daerah (DPPKD) Kabupaten Bintan). Repository Universitas Maritim Raja Ali Haji, 1-29. http://jurnal.umrah.ac.id/archives/5283 
Vol. 2, No. 4, November 2021

Masnila, N. (2014). Mengulas Hasil Pemeriksaan Atas Laporan Keuangan Pemerintah Daerah. Jurnal Ilmiah, 6(2).

Masnun, M. (2018). Good Governance Dan Kualitas Laporan Keuangan Pemerintah: Suatu Kajian Di Pemerintah Daerah Provinsi Jambi. EKONOMIS : Journal of Economics and Business, 2(1), 175. https://doi.org/10.33087/ekonomis.v2i1.41

Mayasari, R. (2016). Evaluasi Penyusunan Laporan Akuntabilitas Kinerja Studi pada Dinas Pekerjaan Umum Pengairan Provinsi Sumatera Selatan [Universitas Gadjah Mada]. http://etd.repository.ugm.ac.id/index.php?mod=penelitian_detail\&sub=PenelitianDetail\& act $=$ view\&typ $=$ html\&buku_id=98677\&obyek_id=4

Mayasari, R., Sunardi, sunardi, \& Febriantoko, J. (2021). Proyeksi Hasil Penyelenggaraan Pemerintah Daerah Melalui Indikator Kinerja Pada Dokumen Rencana Kerja Dan Anggaran (Studi Kasus Pemerintah Kabupaten Wonogiri). FINANCIAL: Jurnal Akuntansi, 7(1), 1-13. https://doi.org/https://doi.org/10.37403/financial.v0i0.195

Patty, M. (2019). Pengaruh Penerapan Good Governance dan Budaya Organisasi terhadap Kualitas Laporan Keuangan dengan Kepemimpinan Transformasional sebagai Pemediasi. Intelektiva:Jurnal Ekonomi, Sosial \& Humaniora, 01(1), 66-82.

Rizal, Y. (2015). Implementasi Prinsip Akuntabilitas Publik dan Kaitannya Dengan Reformasi Birokrasi di Sumatera Barat. In JAKPP : Jurnal Analisis Kebijakan \& Pelayanan Publik (Vol. 1, Issue 1, pp. 17-39). http://journal.unhas.ac.id/index.php/jakpp/article/view/46

Rossieta, H., Martani, D., \& Wardhani, R. (2017). Good governance and the impact of government spending on performance of local government in Indonesia. International Journal of Public Sector Performance Management, 3(1), 77. https://doi.org/10.1504/ijpspm.2017.10003231

Rustariyuni, S. D. (2014). Pengaruh Gini Ratio, Pengeluaran Non Makanan Per Kapita, Belanja Daerah Dan Laju Pertumbuhan Ekonomi Pada Indeks Pembangunan Manusia Kabupaten/Kota Di Provinsi Bali Periode 2004-2012. Piramida, 10(1), 45-55.

Said, J., Alam, M. M., \& Khalid, M. A. (2016). Relationship between good governance and integrity system: Empirical study on the public sector of Malaysia. Humanomics: The International Journal of Systems and Ethics, 32(2), 151-171. https://econpapers.repec.org/RePEc:eme:humpps:v:32:y:2016:i:2:p:151-171

Sari, E. W. (2017). Pengaruh Sistem Pengendalian Intern, Penyajian Laporan Keuangan, Aksesibilitas Laporan Keuangan Dan Gaya Kepemimpinan Terhadap Transparansi Dan Akuntabilitas Pengelolaan Keuangan Daerah Di Kabupaten Indragiri Hulu. JOMFekom, $4(1)$.

Sekaran, U., \& Bougie, R. (2013). Research methods for business. In Research methods for business (p. 436). https://doi.org/10.1017/CBO9781107415324.004

Siregar, A. O. D., \& S, I. M. (2020). Analisis Kinerja Keuangan Pemerintahan ( Studi Kasus : Pemerintahan Kota Depok - Jawa Barat ). Jurnal Image, 9(1), 1-19.

Sugiyono. (2017). Methods of Qualitative Quantitative Research and $R \& D$. Alfabeta.

Sunardi, S., Lena, N. M., \& ... (2020). Comparison of Transparency Index Between Regency and City in South Sumatra and Lampung Province. Ekuilibrium: Jurnal Ilmiah ..., 15(2), 
Vol. 2, No. 4, November 2021

138-150. http://journal.umpo.ac.id/index.php/ekuilibrium/article/view/2603

Tupan, C. A. (2016). Calyptra: Jurnal Ilmiah Mahasiswa Universitas Surabaya Vol.3 No.2 (2014). Calyptra: Jurnal Ilmiah Mahasiswa Universitas Surabaya, 3(2), 1-12.

Ulum, A. S. (2005). Pengaruh Orientasi Etika Terhadap Independensi dan Kualitas Audit Auditor BPK-RI. Jurnal Akuntansi Dan Investasi, 6(1), 1-12.

\section{Copyrights}

Copyright for this article is retained by the author(s), with first publication rights granted to the journal.

This is an open-access article distributed under the terms and conditions of the Creative Commons Attribution license (http://creativecommons.org/licenses/by/4.0/) 